\title{
SOCIAL ASSISTANT WORK MANAGEMENT IN EDUCATION POLICY
}

\author{
A GESTÃO DO TRABALHO DO ASSISTENTE SOCIAL NA POLÍTICA DE EDUCAÇ̃̃O \\ POLIITICA DE GESTIÓN DEL TRABAJO DEL ASISTENTE SOCIAL EN EDUCACIÓN
}

\section{Jaqueline Carvalho Quadrado}

$\mathrm{PhD}$ in Sociology from Universidade de Brasília (UnB). Adjunct Professor at Universidade Federal do Pampa (UNIPAMPA).

jaquelinequadrado@unipampa.edu.br.

0000-0002-5220-3710

\section{Eduardo Lima}

Social Work undergraduation student, Universidade Federal do Pampa (UNIPAMPA). elima2929@gmail.com.

\section{0-0002-6356-5100}

Mailing address: Universidade Federal do Pampa, CURSO DE SERVIÇO SOCIAL. RUA ALBERTO BENEVENUTO, 3200 PASSO. 97670000 - São Borja, RS - Brasil

Received: 10.12 .2020

Accepted: 11.20 .2020

Publicado em: 01.01.2021.

\section{ABSTRACT:}

The study aimed to understand the importance of the Social Worker work management process in Education Policy, more specifically in the Coordination of Social Work Course. It was questioned whether the theoretical and methodological principles of management apply in the federal public sector, where the work to be carried out already obeys a previously planned and orchestrated agenda by the federal sphere, as it obeys plans and goals established by the managing bodies of policies public. Then, it was asked whether it would be possible to build the theoreticalpractical process of management and how to carry it out in the field of professional practice, where the overvaluation of bureaucratic work directly interferes with professional action, a process that contributes to the construction of a practice emptied and uncritical professional. Also in this questioning guideline, it was also asked, what are the theoretical and practical principles of management that the social worker could appropriate as a work tool in his performance in the public sector, where the professional routinely runs into institutional limits and power relations established in the state apparatus. The documentary and bibliographic study was characterized by its exploratory character and qualitative approach. It was considered that the process of valuing bureaucratic work has been gradually encouraging the bureaucratization of practice and the professional void, a fact that conditions professional practice to bureaucratic and routine tasks. Work management and the ability to plan and organize professional action on a purposeful basis become instruments of great importance in the formulation of proposals to face the challenges posed to Social Service professionals.

KEYWORDS: Management; Planning; Education; Social Work; Work.

\section{Introduction}

This paper aims to understand the importance of the management process of the social assistant's work at Universidade Federal do Pampa (Unipampa) - Campus São Borja as a professional environment, aiming to see this as a tool for the possibility of universal rights through a democratic management perspective. The text has been materialized after a series of theoretical and practical questions related to the coordination of the social assistant's work and its applicability in the public sector, specifically in the federal scope of Education Police.

In this regard, it was questioned if the theoretical and methodological principles of coordination applies to the federal public sector, where the work to be done obeys a 
previously planned and orchestrated agenda by the federal scope, since those are subordinated to goals and plans established by public policy management bodies. Then, it was questioned if it was possible to build the theoretical-practical process of management and how to make it happen in the professional field, where the overvaluation of bureaucratic work directly interferer in the professional action, being a process that contributes to the construction of a emptied and uncritical professional practice.

This process of valuing bureaucratic work has gradually stimulated the bureaucratization of practice and the professional void (lamamoto, 2003, p. 161), being that a fact that conditions the professional exercise to the bureaucratic and workaday tasks. Still being in this questioning guideline, it has also been asked what are the theoretical and practical principles that the social assistant could appropriate as a work tool in the public scope actuation, where the professional routinely bumps at the institutional limits and at the power relations established by the state apparatus.

The study proposal has started from the resistance of recognizing the management as a tool of work and of domain of the work assistant. The non-appropriation of certain management principles is based on the lack of knowledge that the category still has about the question. However, due to the revision of the curriculum guidelines for academic education in 1996, the minimum curriculum of the Social Service in Brazil started to demand the curricular component of "management", since it is a important discipline in the curricular organization set and it is also recognized as a work tool dominated by the social assistant.

This paper has been accomplished through documentary and bibliographic study, being the documentary study consisted of covering documents, mainly institutional ones, that contributed for the development of the theme of this paper. The bibliographic research was characterized by its exploratory character and qualitative approach, aiming to highlight the management fundamentals that, properly appropriated, contribute to the realization of professional work in Education Policy scope.

\section{Professional work and management: planning and professional action}

Going through the historical trajectory of the career, the social assistants dedicated themselves to the implementation of public social policies, maintaining an intrinsic relationship with the State and its demands. Knowing that, since the beginning of the profession, Social Work has been present in the various areas of state intervention, as much as a mediator and as an executor of social policies, the social assistant was always 
called to intervene with the manifestations of social issue in the areas of health, education, housing, among others.

In this sense, it its briefly put how were the first approximation of the Social Work with management. According to experts (Nogueira, 2007; Oliveira, 2012; Souza Filho), the field of administration, organization and management started to gain some visibility in Social Work around the 80 s with reconceptualization and rupture movements that the profession was going through.

Rosa (2008) says that the role of Social Work in management has its first records in the study of company Social Work, a field that has been gradually been established not only in Brazil, but also in other countries in Latin America, the United States and Europe.

It is well known that administration and Social Work are two distinct object fields, since Social Work has as its object the social issues and its multiple expressions, whereas administration - or management - can be defined as a [...] rational and measured way of ordering the means to achieve results (Nogueira, 2007, p. 30). The author still points:

[...] the foundation of management, or administration, is the notion of rationality, which is the usa of intelligence or reason to find the most appropriate ways for achieving results. These are defined as objectives to be achieved, while the means concern to the people, to the modes and to the resources that guarantee the achievement of the objective (Nogueira, 2007, p. 31, my translation)

This may pose as a problem for social assistants, but for administrative thinking it is a virtue, since [...] ideally, bureaucracy is the professional management that aims, through rationalization and control of work, the efficiency and maximization of results (Nogueira, 2007, p. 78). Thus, managers must be leaders capable of acting in public management as potentializing agents in the adhesion of the democratic project of society and management. [...] The public manager must have theoreticalmethodological, ethical-political, and technical-operational competence, both to analyze the movements of the economy, politics, society, and to analyze its groups and individuals (Souza Filho, 2013, p. 225).

Filho's argument (2013) is very elucidative when he says that the proposal of social assistants who work in public management is to assume the "democratic public administration", which aims equity, social justice, political participation, accountability and democracy in a direction of universalization and deepening of rights (Souza Filho, 2013 , p. 220). For this author, it is this conception that will distinguish a democratic proposition of public management from a purely technical or market-centered approach. 
Nogueira (1998) contributes for the point of view of management and its operators. For the author, the essential thing in a construction proposal that goes against hegemony in neoliberalism is not in the apprehension of managerial technologies, but in qualification of people to act at the boundary between technique and politics. That way, the development of technical competences and managerial skills aimed at carrying out professional work in the scope of education policy of public management contribute to the replacement of the subordinate and executive agent by a competent and qualified professional for the new required functions of the social assistant.

Undeniably, the most prominent contribution on planning for Social Work is by Myrian Veras Baptista (1978). Planning is conceived by Baptista (1978) as a process of approaching a certain reality through a system supported by technical-operational and scientific concepts. The writer emphasizes that it must be carried out in a continuous cycle of "reflection-decision-action-reflection", thus configuring a dynamic and nonlinear process.

Baptista (1978, p. 14) clarifies the conceptualization of each of these operations. The reflection operation "concerns the knowledge of data, the analysis and study of alternatives, the adaptation and combination of concepts and techniques from disciplines related to the quantification of social facts". The decision operation "refers to the choice of alternatives, the determination of means, the definition of deadlines". The action operation is related to "the execution of decision. It is the central focus of planning". Finally, the review operation consists of a "operation to criticize the effects of the planned action, with a view to supporting subsequent actions". The "reflectiondecision-action-reflection" movement assumed in the planning decision is characterized, according to Baptista, by the following approaches:

"Construction/reconstruction of the object; situation study; definition of objectives for action; formulation and choice of alternatives; assembly of plans, programs and/or projects; implementation; control of execution; evaluation of the process and the action taken; resumption of the process at a new level (2003, p. 28 , my translation)".

Another writer who makes a critical contribution to planning is Pedro Demo (1998). For him, planning, as an instrument used by the State, historically has a strong technocratic, systemic, and imposing propensity. This technocratic propensity is marked by the "power of the technician" that influences "flows and resources, construction of plans and programs, forms of evaluation and monitoring, on behalf of a State, which can be more or less authoritarian" (Demo, 1998, p.42). 
In other words, planning is restricted to the interests of a particular group, the technocrats one. There is a clear distinction between intellectual and manual labor, between those who think and those who perform and between who command and those who carry out orders. This systemic model of planning, according to the aforementioned author, concerns the tendency of not proposing to overcome the system in question. The author points out: "changes are proposed within the system, but not in the system" (Demo, 1988, p. 43).

These functions required of professionals result from a set of new configurations, which requires social assistants' new ways to carry out professional work. For this statement, it is considered that the relationship between the contextual changes verified in the way of organizing the mechanisms of production and reproduction of social and material life, in the means of insertion of the professional in the labor market and the new situations that emerge from this set of relationships, converge towards the construction of a purposeful and articulated professional with new forms of organization and management of professional work.

It is also necessary to consider the reduction of the public machinery as is the case of the contingency of financial resources of educational policies, through new programs of the federal government, which has been presenting new challenges for the career.

In this sense, in order to carry out the work of the social worker in the scope of public management, it is essential that professional action be founded in an organized planning, based on the guidelines of educational policies and curricular guidelines for the undergraduate course and in critical theoretical-practical knowledge about the management of professional work in educational policies, which will, in due course, contribute to direct professional action, in addition to the actions previously directed and limited to the terminal execution of technicality and bureaucracy.

According to Paiva (1999), the management theme and all its theoretical and methodological support is covered with detailed technical recommendations, due to its coming from the administration area. However:

The conceptualization of notions such as efficiency, efficacy and effectiveness; detailing the different management functions, planning, organization, direction and control; the characterization of the different organizational levels - strategic, tactical, operational - find in the relevant bibliography a series of guidelines, analysis and exercises that can be useful and facilitators of the organization of the social worker intervention project, which performs the function of manager in the social area, depending on the use made of them (Paiva, 1999, p. 90, my translation). 
Furthermore, it is important to understand that management is consolidated as a process intrinsic to any activity that involves resources and that aims to achieve some objective. Thus, it is clear that administration, or management, is an activity inseparable from any situation that involves people, resources, and the intention to develop and achieve objectives.

In other words, the process of making decisions about objectives and the use of resources is understood by administration or management. Thus, the administration, or management, is constituted of any process that has the purpose of guaranteeing the efficiency and effectiveness of actions carried out by organizations.

It is important to note that in administration, the administrative process comprises four basic functions for an achieving objectives organization: planning, organization, direction, control, and evaluation.

Planning has the function of defining the process and establishing desired future situations, in addition to considering the resources and necessary means to achieve this situation. The organization is characterized as the process of defining and detailing the work to be carried out, the responsibilities for carrying out and allocating the available resources according to rational criterial. The direction function aims to establish the process of mobilizing and activating resources, especially people, to carry out middle and end activities. The control function is about ensuring the achievement of objectives, as well as identifying and pointing out needs for changes. Generally, control gives rise to continuous evaluations, which directly influences the development of professionals, ensuring the quality of the results of planned actions.

It becomes necessary to say that administration is a science organized by a series of theories, having a systematic body of knowledge based on principles and concepts that deal directly with human beings. So, the theories that underlie management demonstrate that managerial functions can be performed by anyone responsible for some type of organized activity in the organizational scope.

Under this guideline, the social assistant demand skills, and abilities to build interventional modalities in daily work. For such a proposition, he must appropriate theories that enable him to improve the knowledge acquired, focusing on the development of competences and skills in the scope of management as an instrument of work and domain of the social assistant.

However, this process of appropriation goes through the necessary acquisition of knowledge about the concepts and principles that underlie management as a methodology for carrying out professional work. Therefore, it is emphasized that, above all, critical competence is needed to discern purely executive bureaucratic requirements 
of managerial functions that are required from the professional, bearing in mind that the particularities that involve the work of the social assistant postulate a critical stance and committed to the consolidation of social rights, and not to the bureaucratic and alienated execution of social services in the public scope.

It is important to mention that the managerial functions performed by social workers must be in line with the principles and values set out in the Professional Political Ethical Project (PEPP) and with the legal prerogatives that regulates the career, thus aiming at removing professional work from functionalist approaches and allowing progress to be made in democratic approaches.

\section{The Social Service course at Universidade do Pampa}

The bachelor's degree in Social Work started in 2006 in the city of São Borja and lasts for four years, divided into eight semesters. Of a daytime nature and with an interdisciplinary, face-to-face perspective, it was the "first Social Service course created by a Federal Institution of Higher Education in Rio Grande do Sul, given that the first course in a private institution in Rio Grande do Sul already has more than 50 years" (Unipampa, 2016, p. 28). Since its genesis, the institution "aims to train professionals trained to intervene in the various expressions of the social issue, aims to contribute to the development of research and intellectual production related to the study of the social issue and its multiple expressions in Brazilian society" (Unipampa, 2016, p. 7).

The choice for São Borja's city was based on a study where it was possible to perceive a low economic and social development. As a result, the Social Service course was implemented in the municipality due to the "need to build local and regional projects based on the historical conditions of the place, its culture, its resources and its people" (Unipampa, 2016, p. 29) and as a way to expand the labor market and meeting social, economic, cultural, educational, and health needs of the population, based on the implementation of public policies.

The general objective of the course is "to promote higher quality education, with a view to training professionals committed to unveiling and intervening in the social issue and its expressions, based on the principles and values defended by the political and ethical project of Social Work" (Unipampa, 2016, p. 40), so that, in this way, professionals have the ability to execute public policies through a sensitive understanding of the user's reality, placing your specific objectives in:

Prepare professionals based on a critical social theory, which allows the apprehension of the social totality in its dimensions of universality, particularity and uniqueness; Guide professionals committed to the 
social and political direction of the professional project; Train professionals to understand the social meaning of the profession and to unveil the possibilities of intervention contained in reality; Subsidize professionals with theoretical-methodological, ethical-political and technical-operational bases; Train professionals committed to the values and guiding principles of the Professional Code of Ethics; Instruct professionals with clear competences and attributions to apprehend and intervene in the expressions of the social issue, in the different socio-occupational spaces; Provide the training of professionals based on the articulation between teaching, research and extension, fostering problematizations about the particularities of the social issue in the western border regional reality (Unipampa, 2016, p. 40, my translation).

The course seeks no only to develop a reflective awareness in the professional, but also a critical one, where the individual is able to intervene in the user's life and in the expressions of the social question, applying his theoretical knowledge and executing public policies, always committed with is Code of Professional Ethics and its Political Ethical Project.

The implementation of the course on São Borja's campus brought significant changes to the city and the region, so much that a relevant index of trained students was approved in public tenders, master's degrees, doctorates, just as there was an expansion in job field, collaborating a lot for the evolution of the territory (Unipampa, 2016, p. 30). Still in this perspective, professional training must "enable theoretical-methodological and ethical-political training, as a fundamental requirement for execution of technicaloperative activities, with a view to the critical apprehension of social processes, in a perspective of totality" (Unipampa, 1999).

From this brief contextualization about the Social Service Course, it is possible to enter especially in the duties of the Course Coordinator, that are defined in the article 105 of UNIPAMPA General Regulation, established in CONSUNI Resolution, n 5/2010, available, as well as all the other Resolutions, on the page http://porteiras.r.unipampa.edu.br/portais/consuni/resolucoes / .

Art. $5^{\circ}$ The Course Coordination is the executive structure responsible for undertaking the activities necessary to achieve the aims and objectives of the Course that it coordinates, according to relevant legislation, institutional rules, and the Course Pedagogical Project (PPC). Single paragraph. The skills of the Course Coordination are described in the UNIPAMPA General Regulations, Campus and Course (Unipampa, 2019, p. 2, my translation).

We highlight below the attributions that, from the point of view, deserve to be highlighted (although all others are important and should be known by the coordinator): 
Art. 105. The Course Coordinator is responsible for carrying out the activities necessary to achieve the aims and objectives of the Course he coordinates, among them: II. promote the implantation of the Course proposal, [...] and a continuous evaluation of the Course quality, together with the faculty and student; III. forward to Organs competent bodies, [...] the proposals for curricular changes approved by the Course Committee; IV. formulating diagnoses about the problems existing in the Course and promoting actions aimed at overcoming them; VII. serve as the first instance of decision in relation to the administrative and academic problems of the Course [...]; IX. comply with or promote the effectiveness of the decisions of the Course Committee; XII. report to the Academic Coordinator the issues related to disciplinary problems related to civil servants and students who are related to the Course he coordinates; XIV. provide, in accordance with the guidelines of the Teaching Committee, the plans for all subjects of the Course, $[. ..] ; \mathrm{XV}$. contribute to the Academic Coordination to control and record the academic life of the Course in its various forms; XVI. guide the students of the Course in the enrollment and in the organization and selection of their curricular activities; XXI. promote curricular adaptation for incoming students with transfer, use of disciplines, locking and in other cases provided for by law; XXII. meet the demands of the Academic Coordination throughout the process of obtaining the degree of your course. Academic and pedagogical aspects are dealt with in the definition of the Course Committee (Art. 97), of which the coordinator is president (Unipampa, 2010, p. 27-28, my translation)

Textually, the article 97 tell us that:

The Course Committee is the body whose purpose is to make the construction and implementation of the Course Pedagogical Project feasible, curriculum changes, the discussion of topics related to the course, as well as to plan, execute and evaluate the respective academic activities (Unipampa, 2010, p. 26, my translation).

It is noteworthy that the Course Committee is chaired by the Coordinator and composed of all the preceptors who wort in the course, as well as the representations of students and technical-administrative jobs in education. Thus, there is a co-responsibility between all the actors who play roles in an undergraduate course to take the pedagogical project of that course to the next level. Within the Course Committee, a smaller group of teachers has more specific duties.

The idea of the NDE arises from the finding that a good undergraduate course has some members of its faculty that help to build its identity. It is not a matter of personifying a course, but of recognizing that education is done with people and that there is, in every social group, a leadership process that is beyond the instituted positions. If the identity of a course depends on these people who are references, both for students and for the academic community in general, it is fair to understand and encourage their recognition, institutionally, to qualify the design, consolidation and even the constant updating of a pedagogical course project. This can prevent PPCs from being merely a documentary piece (Unipampa, 2010, p. 11, my translation). 
The regulation of Structuring Teaching Groups by the Ministry of Education took place via CONAES Resolution no 1/2010. At UNIPAMPA, Resolution No. 97, of March 19, 2015, establishes the Structuring Teaching Nucleus (NDE) and establishes its operating rules.

Furthermore, the course coordinators are responsible or co-responsible for several processes related not only to the implementation of the political-pedagogical project, but also to the control and institutional academic record. As in general the processes related to academic records are more technical and more dependent on legislation and internal rules, the coordinator follows the internal rules already pre-established for theses flows.

Exercising the role of management means carrying out the planning of the actions that will be developed and the objectives that are to be achieved. Following Baptista (2015, p. 14), "based on the outline, it is possible to go deeper into the problematic and the intentionality of the issue, define the objectives precisely and, thus, achieve the desired results in the process".

Therefore, in this intense field of historical social disputes, there are Social Service professionals that are increasingly assuming management positions, basically in the formulation, execution, and control of the implementation of the education policy.

\section{Final Considerations}

Through the brief reflection presented here and, in order to offer theoretical subsidies of management for Social Work, this study sought to deepen the theory and build knowledge around the theme presented, as well as contribute to the growth of Social Work, especially in the area of management and professional work.

It was observed that the professional faced difficulties in creating, recreating, and implementing work proposals consistent with the reality presented daily. However, through Reading and considering the profession's ethical-political commitment and position in defense of social and human rights, it is necessary to build concrete and coherent work plans that enable users of Education Policy, access to constitutionally guaranteed rights.

From this perspective, it was considered that work management and the ability to analyze, reflect, plan and organize professional action become important instruments in the construction of a purposeful practice, capable of overcoming the contradictions posed by the current system and consolidating the values and principles set in the ethical-political project of the profession. 
The professional must be open to incorporating the principles of management in daily work. So aiming contribute to the construction of a new professional profile, capable of consciously responding to emerging demands in society, through purposeful professional exercise based on previously planned actions, founded on knowledge and mastery of management principles, as well as on the theoretical and practical dimensions postulated Social Service and that justify professional practice.

\section{References}

BAPTISTA, Myrian Veras. (1978). Planejamento: introdução à metodologia do planejamento social. $2^{a}$ edição. São Paulo, Cortez \&Moraes ltda.

BAPTISTA, Myrian Veras. (2015). Planejamento social: intencionalidade e instrumentação. São Paulo, Veras.

DEMO, Pedro. (1988). Participação é conquista. São Paulo, Cortez.

FILHO, Rodrigo de Souza. (2013). Gestão Pública \& Democracia: A Burocracia em Questão. 2.ed. Rio de Janeiro, Lumen Juris.

IAMAMOTO, Marilda Vilela. (2001). O Serviço social na Contemporaneidade: trabalho e formação profissional. 5. Ed. São Paulo, Cortez.

NOGUEIRA. A.M. 2007. Teoria da Administração para o século XXI. São Paulo, Ática Universidade.

ROSA. J.S. da. (2008). A matéria Administração e Planejamento na Matriz Curricular do curso de Serviço Social. Dissertação Mestrado em Serviço Social - Universidade Federal de Santa Catarina. Florianópolis.

PAIVA, Beatriz Augusto. (1999). Reflexões sobre pesquisa e processos de formulação e gestão.In. Capacitação em Serviço Social e Política Social: Módulo 4: O trabalho do assistente social e as Políticas Sociais. Brasília, CEAD.

UNIPAMPA. Universidade Federal do Pampa. Edital da Pró-Reitoria de Graduação (PROGRAD). (2019b). Edital n 62/2019. Bagé.

UNIPAMPA. (2016). Universidade Federal do Pampa. Projeto Pedagógico do Curso de Serviço Social - Bacharelado. São Borja.

UNIPAMPA. (2019) Universidade Federal do Pampa. Conselho Universitário da Universidade Federal do Pampa. Resolução n 253, de 12 de setembro de 2019. 


\section{Crevisto Observatório}

http://dx.doi.org/10.20873/uft.2447-4266.2021v7n1a11en

\section{RESUMO:}

O estudo objetivou compreender a importância do processo de gestão do trabalho do Assistente Social na Política de Educação, mais especificamente na Coordenação de Curso de Serviço Social. Questionou-se, se os princípios teóricos e metodológicos da gestão se aplicam no setor público federal, onde o trabalho a ser realizado já obedece a uma agenda previamente planejada e orquestrada pela esfera federal, por obedecer a planos e metas estabelecidas pelos órgãos gestores das políticas públicas. Em seguida, foi questionado, se seria possível construir o processo teórico-prático da gestão e como efetivá-lo no campo de atuação profissional, onde a supervalorização do trabalho burocrático interfere diretamente na ação profissional, processo esse que contribui para a construção de uma prática profissional esvaziada e acrítica. Ainda nesta diretriz de questionamentos, também se perguntou, quais os princípios teóricos e práticos da gestão que $\mathrm{o}$ assistente social poderia se apropriar enquanto instrumento de trabalho em sua atuação no setor público, onde o profissional, esbarra rotineiramente nos limites institucionais e nas relações de poder estabelecidas no aparelho estatal. O estudo documental e bibliográfico caracterizou-se por seu caráter exploratório e abordagem qualitativa. Considerou-se que o processo de valorização do trabalho burocrático vem gradativamente estimulando a burocratização da prática e o vazio profissional, fato que condiciona o exercício profissional ao tarefismo burocrático e rotineiro. A gestão do trabalho e a capacidade de planejar e organizar propositivamente a ação profissional tornam-se instrumentos de grande importância na formulação de propostas de enfrentamento aos desafios postos ao profissional de Serviço Social.

PALAVRAS-CHAVES: Gestão; Planejamento; Educação; Serviço Social; Trabalho.

\section{RESUMEN:}

El estudio tuvo como objetivo comprender la importancia del proceso de gestión del trabajo del trabajador social en la Política Educativa, más específicamente en el Curso de Coordinación del Trabajo Social. Se cuestionó si los principios teóricos y metodológicos de gestión se aplican en el sector público federal, donde el trabajo a realizar ya obedece a una agenda previamente planificada y orquestada por la esfera federal, ya que obedece a los planes y objetivos establecidos por los órganos directivos de Políticas públicas. Luego, se preguntó si sería posible construir el proceso teórico-práctico de gestión y cómo llevarlo a cabo en el campo de la práctica profesional, donde la sobrevaloración del trabajo burocrático interfiere directamente con la acción profesional, un proceso que contribuye a construcción de una práctica profesional vacía y no crítica. También en esta guía de preguntas, también se preguntó cuáles son los principios teóricos y prácticos de gestión que el trabajador social podría apropiarse como herramienta de trabajo en su desempeño en el sector público, donde el profesional se topa habitualmente con límites institucionales y relaciones de poder establecidas. en el aparato del estado. El estudio documental y bibliográfico se caracterizó por su carácter exploratorio y enfoque cualitativo. Se consideró que el proceso de valoración del trabajo burocrático ha estado alentando gradualmente la burocratización de la práctica y el vacío profesional, un hecho que condiciona la práctica profesional a las tareas burocráticas y rutinarias. La gestión del trabajo y la capacidad de planificar y organizar la acción profesional con un propósito determinado se convierten en instrumentos de gran importancia en la formulación de propuestas para enfrentar los desafíos planteados a los profesionales del Trabajo Social.

PALABRAS-CLAVES: Gestión; Planificación; Educación; Trabajo Social; Trabajo. 